\title{
MECHANICAL PROPERTIES OF CONCRETE CONTAINING RECYCLED CONCRETE AGGREGATES SUBJECTED TO DIFFERENT FIRE DURATIONS
}

\author{
Associate Prof., Walid Safwat Fahmy, \\ Faculty of petroleum Engineering and Mining, Suez Canal University, \\ Suez, EGYPT. Email :Walid.Fahmy@gmail.com

\section{Lecture, Erfan Abdel-Latif Heneidy,} \\ Civil Engineering Dept., Faculty of Engineering, Suez Canal University, \\ Ismailia, EGYPT.

\section{Lecture, Esraa Emam Ali,} \\ Material Dept., Housing and Building National Research Center-Dokki- \\ Cairo, EGYPT.

\section{Ibrahim Saad Mohammed Agwa,} \\ Civil Structures Dept., Faculty of Industrial Education, Suez Canal Univ., \\ Suez, EGYPT.
}

\section{(Received July 4, 2011 Accepted August 7, 2011)}

The amount of construction and demolition waste has increased considerably over the last few years. Crushing concrete to produce coarse aggregate for the production of new concrete is one common means for achieving a more environment-friendly concrete. This experimental study demonstrates the mechanical properties of concrete containing recycled concrete aggregate $(R C A)$ subjected to different fire durations. In the experimental work, the fresh concrete properties (slump test) and the hardened concrete properties, (compressive strength, splitting tensile strength, flexural strength and modulus of elasticity) were carried out. A total of thirty concrete mixes with different cement contents $(300,350$, and $400 \mathrm{Kg} / \mathrm{m3})$ at $\mathrm{w} / \mathrm{c}$ ratio $(0.5)$ were made and the percentage of substitution of natural concrete coarse aggregate by the recycled concrete coarse aggregate subjected to fire durations (1,2 and 3 hours) at fire temperature $\left(600^{\circ} \mathrm{C}\right)$ was $(0 \%, 25 \%, 50 \%$ and $100 \%)$. In the process of mixing, equal consistence among all concrete mixes was achieved. The obtained results indicate that the recycled coarse aggregate subjected to fire can successfully be used for making structural concrete.

KEYWORDS: Recycled concrete aggregate, fire duration, Compressive strength. Tensile strength, Flexural strength and Modulus of elasticity

\section{INTRODUCTION}

Shortage of natural aggregate in urban environments and increasing distance between the sources of quality natural aggregate and construction sites compelled the constructors to consider substituting the natural aggregate by recycled material (construction ceramics, slag, concrete). On the other hand, large quantities of old 
concrete often occur in urban environments, whose removal and disposal presents an environmental problem. Many authors from different countries study this point. Solomon et al, [1] Marked an aggregate which is brought from demolished masonry and concrete structures as potentially good for use in new concrete. Scope of usage of recycled materials is determined by their quality. In general, the quality of recycled aggregate depends on the quality of the original concrete it was obtained from, so prior to the design of mixture; aggregates must be examined in detail. Tabsh and Abdelfatah, [2] Conclude that the percentage loss in compressive or tensile strength due to the use of recycled aggregate is more significant in a weak concrete than in stronger one. The use of coarse aggregate made from recycled concrete with strength equal to $50 \mathrm{MPa}$ will result in concrete compressive and tensile strengths comparable with that achieved when using natural coarse aggregate. Recycled concrete mixes require more water than conventional concrete to maintain the same slump without the use of admixtures, regarding that it is a relatively new material [3].

Concrete is a composite material consisting of aggregates and matrix as its basic components. The effect of heating on both these components individually as well as their interaction control the behavior of concrete at high temperatures. Purkiss, [4] Concrete is a porous material with its pores filled with water and air. Surface heating of the concrete at elevated temperatures during fire not only results in deterioration of its properties like elastic modulus, tensile and compressive strength, but also in moisture migration in the presence of liquid water, heat evolved from fire to the concrete, causes the evaporation of liquid water. With the rise in temperature, the aggregate expands, the expansion of the matrix, on the other hand, is substantially offset of sometimes completely negated by shrinkage due to the evaporation of water. The resultant expansion differential causes internal cracking in the concrete and reduction in its stiffness. The extent of this phenomenon differs considerably with the type of aggregate and is most pronounced in the case of concrete with siliceous aggregate which at very high temperatures $\left(575^{\circ} \mathrm{C}\right.$ or above) also undergoes physical changes accompanied by a sudden expansion in volume, thus sometimes causing aggregate splitting and / or spalling. Concrete is a poor conductor of heat, but can suffer considerable damage when exposed to fire. Unraveling the heating history of concrete is important to forensic research or to determine whether a fire-exposed concrete structure and its components are still structurally sound, [5]. At temperatures of 70-80 ${ }^{\circ} \mathrm{C}$ ettringite dissociates and at about $100{ }^{\circ} \mathrm{C}$ the water physically bound in both the aggregates and the cement matrix starts to evaporate, increasing capillary porosity and microcracking at these relatively low temperatures, concrete may only experience a minor loss of strength. At temperatures ranging from 250 to $300{ }^{\circ} \mathrm{C}$ the loss of bound water in the cement matrix becomes more prominent a significant loss of strength is often observed. Up to $600{ }^{\circ} \mathrm{C}$, most aggregates undergo thermal expansion and the consequent internal stresses give rise to extensive cracking at $600{ }^{\circ} \mathrm{C}$ the mechanical performance of concrete is already severely affected. From 600 to $800{ }^{\circ} \mathrm{C}$, carbonates suffer decarbonation for calcareous aggregates, a considerable contraction may occur (due to the release of carbon dioxide) causing severe microcracking of the cement matrix. Finally, from 800 to $1200{ }^{\circ} \mathrm{C}$, calcareous constituents suffer complete disintegration concrete becomes a calcinated material [6]. Producing concrete with recycled aggregate subjected to fire has still been inadequately researched field. So the effect of using aggregate obtained from demolished concrete has been studied 
previously in several researchers, while in the current study the recycled aggregate resulting from concrete subjected to fire will be used and its effect on the properties of concrete will be studied.

\section{EXPERIMENTAL PROGRAM}

\subsection{Materials}

\subsubsection{Cement}

The cement used in this investigation was CEM I $42.5 \mathrm{~N}$. Testing of cement was carried out as per the Egyptian Standard Specifications ESS 2421/2005 [7]. Mechanical and physical properties and the chemical analysis of the used cement are given in Tables (1) and (2) respectively.

Table (1): Mechanical and Physical Properties of Cement

\begin{tabular}{|c|c|c|c|}
\hline \multicolumn{2}{|c|}{ Property } & Results & $\begin{array}{c}\text { Specifications } \\
\text { Limits* }\end{array}$ \\
\hline $\begin{array}{c}\text { Compressive Strength of Standard } \\
\text { Mortar (MPa) }\end{array}$ & 2 days & 21.4 & Not less than 10 \\
\cline { 2 - 4 } & 28 days & 47.7 & $\begin{array}{c}\text { Not less than } 42.50 \\
\text { Not more than } 62.5\end{array}$ \\
\hline \multicolumn{2}{|c|}{ Soundness (La Chatelier) (mm) } & 1 & Not more than 10 \\
\hline Setting Time (min) & Initial & 135 & Not less than 60 \\
\cline { 2 - 4 } & Final & 180 & ------- \\
\hline
\end{tabular}

*Limits of ESS 4756-1 / 2007 [7]

Table (2): Chemical Properties of Cement

\begin{tabular}{|c|c|}
\hline Property & Results \\
\hline Silicon Oxide SiO2 & 21.0 \\
\hline Aluminum Oxide Al2O3 & 6.10 \\
\hline Ferric Oxide Fe2O3 & 3.00 \\
\hline Calcium Oxide CaO & 61.5 \\
\hline Magnesium Oxide MgO & 3.8 \\
\hline Sulfur Oxide SO3 & 2.5 \\
\hline Sodium Oxide Na 2O & 0.4 \\
\hline Potassium Oxide K2O & 0.3 \\
\hline Loss on Ignition (L.O.I) & 1.6 \\
\hline Insoluble Residue & 0.9 \\
\hline
\end{tabular}

\subsubsection{Fine Aggregates}

Natural sand composed of siliceous materials was used as Fine Aggregate (FA) in this study. Testing of sand was carried out according to the ESS 1109/2002 [8]. Table (3) shows the physical properties of the sand. 
Table (3): Physical Properties of Fine Aggregate

\begin{tabular}{|c|c|c|}
\hline Property & Results & Limits* \\
\hline Specific Weight & 2.63 & ---- \\
\hline Bulk Density (t/m3) & 1.78 & ---- \\
\hline Clay and Fine Dust Content (\% By Volume) & 1.4 & Not more Than 3 \\
\hline
\end{tabular}

*Limits of ESS 1109 /2002 [8]

\subsubsection{Coarse aggregates}

\subsubsection{Natural coarse aggregates}

Natural crushed stone (dolomite) was used in this study. Testing of natural coarse aggregate (NCA) was carried out according to the ESS 1109/2002 [8]. Mechanical and physical properties of the NCA comply with both ESS 1109/2002 [8] and the Egyptian Code ECCS203-2007 [9]. Table (4) shows the physical and mechanical properties of the Natural crushed stone (dolomite).

Table (4): Physical and Mechanical Properties of Natural Coarse Aggregate

\begin{tabular}{|c|c|c|}
\hline Property & Results & Limits \\
\hline Specific Weight & 2.61 & ---- \\
\hline Bulk Density (t/m3) & 1.56 & ---- \\
\hline Water Absorption \% & 2.05 & Not more than $2.5^{* *}$ \\
\hline Clay and Fine Dust Content & 2.4 & Not more than $4 *$ \\
\hline Flakiness Index \% & 36.8 & Not more than $40^{*}$ \\
\hline Elongation Index \% & 9.6 & Not more than $25^{* *}$ \\
\hline Abrasion Index \% & 17.8 & Not more than $30^{*}$ \\
\hline Impact Value \% & 12.60 & Not more than $45^{*}$ \\
\hline
\end{tabular}

*Limits of ESS 1109/2002 [8]

**Limits of ECCS203-2007 [9]

\subsubsection{Fired Recycled coarse aggregates}

The recycled coarse aggregate used in this study were produced by crushing the concrete elements subjected to fire. Jaw crusher type (BB300) was used to gash the fined elements into wise recycled aggregate with fraction size $10 \mathrm{~mm}$.

Testing of (RCA) was carried out according to the ESS 1109/2002 [8]. The physical and mechanical properties of the RCA are shown in Table (5). 
Table (5): Physical and Mechanical Properties of Recycled Coarse Aggregates

\begin{tabular}{|c|c|c|c|c|}
\hline \multirow{2}{*}{ Property } & \multicolumn{3}{|c|}{ Results } & \multirow{2}{*}{ Limits } \\
\cline { 2 - 4 } & $\begin{array}{c}\mathbf{6 0 0}^{\circ} \mathbf{C}- \\
\mathbf{1 h r}\end{array}$ & $\begin{array}{c}\mathbf{6 0 0}^{\circ} \mathbf{C}- \\
\mathbf{2 h r s}\end{array}$ & $\begin{array}{c}\mathbf{6 0 0}^{\circ} \mathbf{C}- \\
\mathbf{3 h r s}^{*}\end{array}$ & \\
\hline Specific Weight & 2.18 & 2.20 & 2.15 & ---- \\
\hline Bulk Density (t/m3) & 1.25 & 1.51 & 1.31 & ---- \\
\hline Water Absorption \% & 4.95 & 6.65 & 7.65 & Not more than $2.5^{* *}$ \\
\hline $\begin{array}{c}\text { Clay and Fine Dust } \\
\text { Content \% }\end{array}$ & 7 & 10 & 13 & Not more than $4^{*}$ \\
\hline
\end{tabular}

*Limits of ESS 1109/2002 [8]

\subsubsection{Mixing water}

Drinking water was used for mixing.

\subsubsection{Superplasticizer}

In this study, In order to obtain same workability without increased water, super plasticizer admixture ADDICRETE BV was used. ADDICRETE BV is a superplasticizer and flowing concrete admixture. (Complies with ASTM C $494-80$ type A, DIN 10045, BS 5075PART1). Following properties, base material was lingo sulphonates, density was $1.18 \pm 0.01 / 1$ at $25^{\circ} \mathrm{C}$ and it was combatable with types of Portland cement.

\subsection{Test setup of fire furnace and the Jaw crusher type BB300}

The fire furnace was designed for the purposes of fire; the fire furnace system consists of three main components the fire chamber the fire lighter, and temperature control system as shown in Figure (1). The crusher used in this study was jaw crusher (type BB300) was shown in Figure (2).

\subsection{Concrete mixes}

The concrete mixes were prepared in the laboratory of Housing and Building National Research Center. A total of thirty concrete mixtures were made with different cement contents $\left(300,350\right.$, and $\left.400 \mathrm{~kg} / \mathrm{m}^{3}\right)$ at $\mathrm{w} / \mathrm{c}=(0.5)$, the superplasticizer dosage varied from $0.6 \%$ to $2.9 \%$ of cement content to achieve the required level of workability defined by a slump value of $10 \pm 2 \mathrm{~cm}$. The percentage of substitution of natural concrete coarse aggregate by the recycled concrete coarse aggregate subjected to fire temperature $600^{\circ} \mathrm{C}$ for fire durations $(1,2$, and 3hours) was $(0 \%, 25 \%, 50 \%$ and $100 \%)$. Control mixes made with the natural aggregate, and the other concrete mixes were made using a recycled concrete aggregates subjected to fire, the ratio of fine to coarse aggregate was about 1:2 .Composition of designed mixtures has been shown in Table (6). 


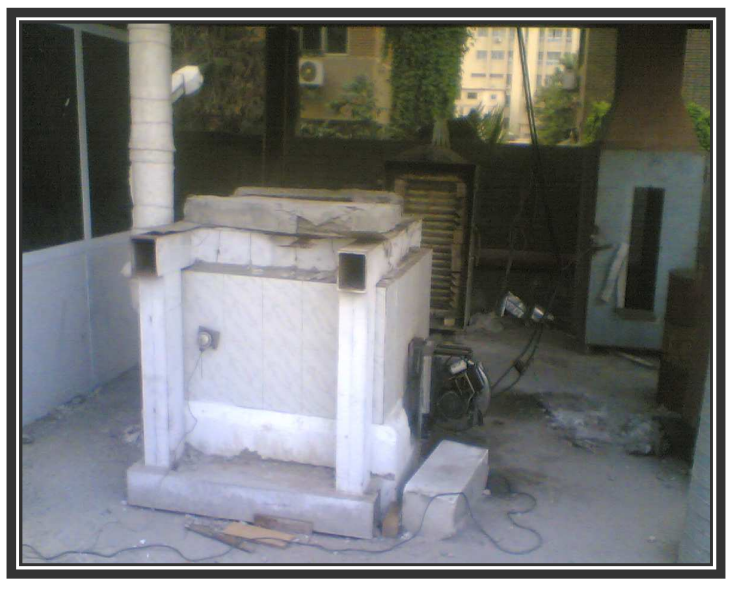

Fig (1) Test setup of fire furnace

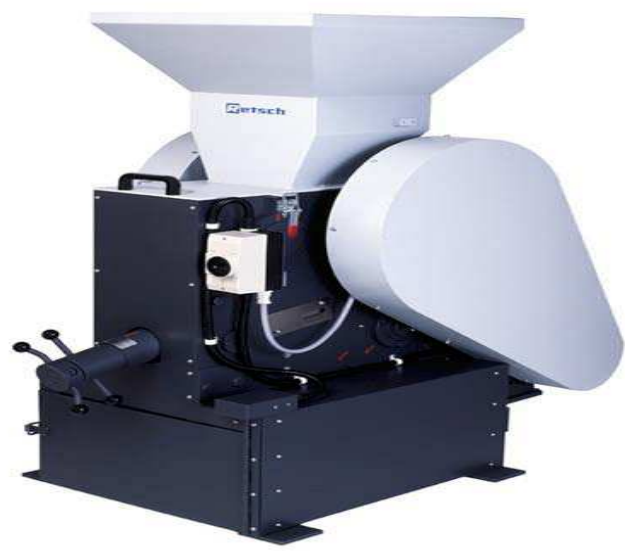

Fig (2) Jaw crusher BB300

Table (6): Concrete Mixes Proportions at Fire Temperature $600^{\circ} \mathrm{C}$ for Fire Durations (1, 2, and 3 Hours)

\begin{tabular}{|c|c|c|c|c|c|c|c|c|c|}
\hline \multirow{2}{*}{ Mix NO. } & \multirow{2}{*}{ Designation } & \multirow{2}{*}{$\mathbf{W}$} & \multicolumn{3}{|c|}{ SP } & \multirow{2}{*}{$\mathbf{C}$} & \multirow{2}{*}{ FA } & \multirow{2}{*}{ NCA } & \multirow{2}{*}{ FRCA } \\
\hline & & & 1hr & $2 \mathrm{hrs}$ & 3hrs & & & & \\
\hline Control & M1 (M-0\% -300) & 150 & 1 & 1 & 1 & 300 & 659 & 1317 & - \\
\hline \multirow{3}{*}{$\begin{array}{c}\text { G1 }(1,2 \\
\text { and } 3 \text { hrs }) \\
9 \text { mixes }\end{array}$} & M2 (M-25\%-300) & 150 & 1.15 & 1.2 & 1.3 & 300 & 638 & 957 & 319 \\
\hline & M3 (M-50\%-300 ) & 150 & 1.7 & 1.9 & 1.95 & 300 & 618 & 618 & 618 \\
\hline & M4 (M-100\%-300) & 150 & 2.6 & 2.8 & 2.9 & 300 & 582 & - & 1164 \\
\hline Control & M5 (M-0\%-350 ) & 175 & 0.8 & 0.8 & 0.8 & 350 & 623 & 1246 & - \\
\hline \multirow{3}{*}{$\begin{array}{c}\text { G2 }(1,2 \\
\text { and } 3 \text { hrs }) \\
9 \text { mixes }\end{array}$} & M6 (M-25\%-350 ) & 175 & 1 & 1.1 & 1.2 & 350 & 604 & 906 & 302 \\
\hline & M7 (M-50\%-350 ) & 175 & 1.35 & 1.45 & 1.6 & 350 & 585 & 585 & 585 \\
\hline & M8 (M-100\%-350) & 175 & 2.3 & 2.45 & 2.55 & 350 & 550 & - & 1100 \\
\hline Control & M9 (M-0\% - 400) & 200 & 0.6 & 0.6 & 0.6 & 400 & 588 & 1176 & - \\
\hline \multirow{3}{*}{$\begin{array}{c}\text { G3 }(1,2 \\
\text { and } 3 \text { hrs }) \\
9 \text { mixes }\end{array}$} & M10 (M-25\%-400) & 200 & 0.9 & 1 & 1.1 & 400 & 569 & 854 & 285 \\
\hline & M11 (M-50\%-400) & 200 & 1.25 & 1.3 & 1.45 & 400 & 551 & 551 & 551 \\
\hline & M12 (M-100\%-400) & 200 & 1.7 & 1.9 & 2 & 400 & 519 & - & 1038 \\
\hline
\end{tabular}

$\mathrm{W}=$ Water $\left(\mathrm{Litre} / \mathrm{m}^{3}\right)$

SP\%; Superplasticizer percentage of cement content

$\mathrm{C}\left(\mathrm{kg} / \mathrm{m}^{3}\right)=$ Cement content

FA $\left(\mathrm{kg} / \mathrm{m}^{3}\right)=$ Fine aggregates (sand)

NCA $\left(\mathrm{kg} / \mathrm{m}^{3}\right)=$ Natural coarse aggregates

FRCA $\left(\mathrm{kg} / \mathrm{m}^{3}\right)=$ Fired Recycled coarse aggregates 


\subsection{Concrete Tests}

All the concrete mixes were mixed in the laboratory of Housing and Building National Research Center (HBRC). The slump test was conducted on fresh concrete to determine the slump value. For each concrete mix, six $150 * 150 * 150 \mathrm{~mm}$ cubes were cast for the determination of compressive strength at 7 and 28 days. Three $150 \mathrm{~mm} *$ $300 \mathrm{~mm}$ cylinders were cast for the determination of indirect tensile strength at 28 days. Three beams of dimensions $100 * 100 * 500 \mathrm{~mm}$ were cast for the determination of flexural strength at 28 days. Two $150 \mathrm{~mm} * 300 \mathrm{~mm}$ cylinders were cast for the determination of static modulus of elasticity at 28 days. After casting, all the cast specimens were covered by plastic sheets and water saturated burlap and left in the laboratory at $20 \pm 3{ }^{\circ} \mathrm{C}$ for $24 \mathrm{~h}$. the specimens were then demoulded and transferred to a saturated water curing tank at $25^{\circ} \mathrm{c}$ until the age of testing.

\section{RESULTS AND DISCUSSION}

\subsection{Properties of Fired Recycled Coarse Aggregate Water absorption}

The water absorption of fired recycled coarse aggregates is much higher than that of the natural coarse aggregates due to the large amounts of old mortar and cement paste attached to fired recycled coarse aggregates and dehydration. The water absorption of fired recycled coarse aggregates is ranged from $4.95 \%$ to $7.65 \%$.

\section{Specific gravity}

The large amount of old mortar and cement paste adhering to fired recycled coarse aggregates, their specific gravity will be $15 \%$ to $17 \%$ lower than that of the natural coarse aggregates. The specific gravity of fired recycled coarse aggregates is ranged from 2.15 to 2.20 .

\section{Bulk Density}

The bulk density of fired recycled coarse aggregates obtained from fired concrete at $600^{\circ} \mathrm{C}$ temperature for fire durations $(1,2$, and 3 hours) are $19 \%, 3 \%$ and $16 \%$ respectively lower than that of natural coarse aggregate.

\subsection{Fresh concrete properties}

The dosage of superplasticizer added to different concrete mixes to maintain a constant slump of $10 \pm 2 \mathrm{~cm}$ was shown in figure (3).

Figure (3) shows the comparison between concrete groups $\left(600^{\circ} \mathrm{C}-1 \mathrm{hr}, 600^{\circ} \mathrm{C}\right.$ $-2 \mathrm{hrs}$, and $600^{\circ} \mathrm{C}-3 \mathrm{hrs}$ ), it can be noticed that the dosage of superplasticizer was increased significantly by increasing the percentage of replacement of FRCA and fire duration.

In general, recycled concrete needed more superplasticizer dose than the control concrete (without recycled materials) regardless of fire duration, and this agree with D. M. Sadek [10] who found that the recycled concrete needed more superplasticizer dosage than the control concrete (without recycled materials) regardless of $w / c$ ratio or type of recycled materials. 


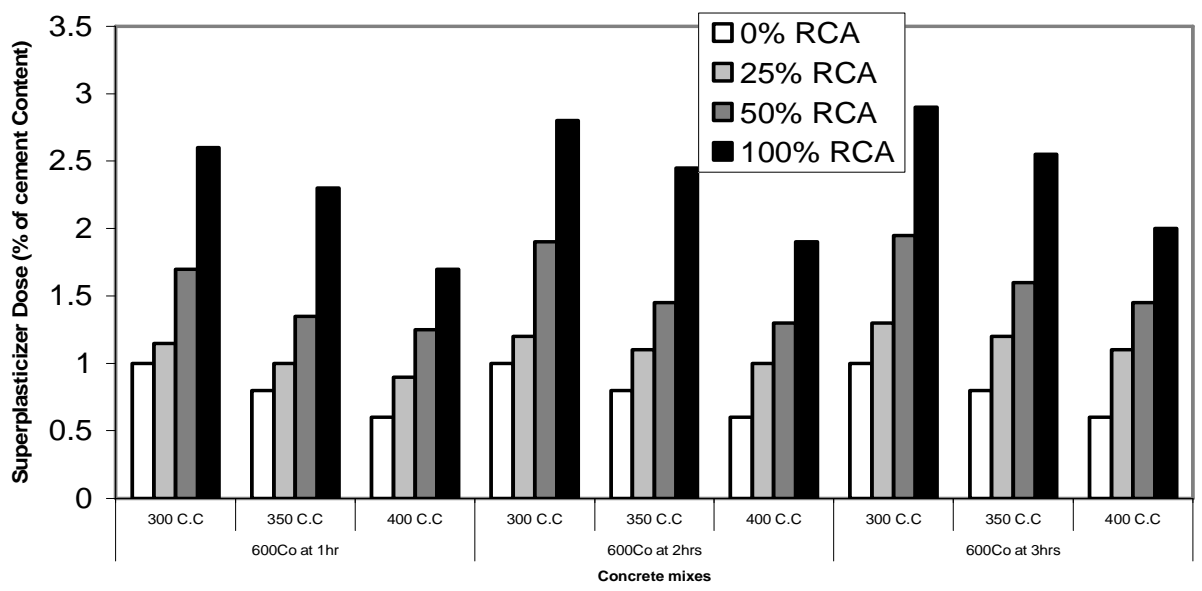

Fig (3): Superplasticizer Dosage for Concrete Mixes

\subsection{Hardened concrete properties Compressive strength}

The compressive strength results at 7 and 28 days of concrete mixtures subjected to fire temperature $600^{\circ} \mathrm{C}$ for fire durations $(1,2$, and 3 hours) were presented in Table (7).

It was observed that the compressive strength of concrete mixtures with percentage of replacement ratios of FRCA $(0 \%, 25 \%, 50 \%$ and 100\%)were increased by $(26 \%, 35 \%, 25 \%$ and $30 \%),(28 \%, 31 \%, 22 \%$ and $20 \%)$ and $(34 \%, 36 \%, 29$ and $25 \%)$ at cement contents 300,350 and $400 \mathrm{~kg} / \mathrm{m}^{3}$ from 7 to 28 days, respectively, at fire duration 1hour.

Figure (4-a) shows the concrete mixtures subjected to fire temperature $600^{\circ} \mathrm{C}$ for 1hour, it can be noticed that at replacement ratio 25\% FRCA, there is a slight increase in the compressive strength by (2\% and 1\%) at cement contents of (300 and $350 \mathrm{~kg} / \mathrm{m}^{3}$ ) respectively, the compressive strength at cement content $400 \mathrm{~kg} / \mathrm{m}^{3}$ decreased by $1 \%$ comparing to control mixtures at 28 days. This agree with Etxeberria et al, [11].Who found that the results up to $25 \%$ RCA has no major effect on compressive strength, and also with F.A. El-Latif, [12].Who reported that there is an increase in the compressive strength at replacement ratio $25 \%$ by ( $4 \%$ and $2 \%$ ) for cement contents $\left(350\right.$ and $\left.400 \mathrm{~kg} / \mathrm{m}^{3}\right)$ respectively, comparing to control mixtures at 28 days. (Notice that the RCA used in the previous studies was not exposed to fire). While at replacement ratios (50\% and 100\%) FRCA, there is a reduction in the compressive strength by (10\% and $17 \%),(13 \%$ and $21 \%)$ and $(13 \%$ and $20 \%)$ at cement contents 300,350 and $400 \mathrm{~kg} / \mathrm{m}^{3}$ respectively, comparing to control mixtures at 28 days. This may be attributed to the weak bond between the fresh mortar and the old mortar adhering to the fired recycled coarse aggregates in addition to the low resistance of the fired recycled coarse aggregates to the mechanical action compared with the natural aggregates.

Figure (4-b) shows the concrete mixtures subjected to fire temperature $600^{\circ} \mathrm{C}$ for 2 hours, it can be demonstrated that at replacement ratio 25\%FRCA, there is a slight decrease in the compressive strength of concrete by 3\% at cement contents (300 and $350 \mathrm{~kg} / \mathrm{m}^{3}$ ), while the compressive strength decreased by $4 \%$ at cement content 400 
$\mathrm{kg} / \mathrm{m}^{3}$. At replacement ratios $(50 \%$ and $100 \%) \mathrm{FRCA}$, there is a reduction in the compressive strength by $(18 \%$ and $24 \%)$, (19\% and $30 \%)$ and $(18 \%$ and $28 \%)$ at cement contents 300,350 and $400 \mathrm{~kg} / \mathrm{m}^{3}$ respectively, comparing with control mixes.

Also, figure (4-c) shows the concrete mixtures subjected to fire temperature $600^{\circ} \mathrm{C}$ for 3 hours, it can be noticed that as fire temperature and fire duration increased there is a significant disintegration of the calcium silicate hydrate as well as partial disintegration occurs in the aggregate. Where at replacement ratio $25 \%$ FRCA, there is a reduction in the compressive strength of concrete by $7 \%$ at cement contents $(300$ and $350 \mathrm{~kg} / \mathrm{m}^{3}$ ) and decreased by $10 \%$ at cement content $400 \mathrm{~kg} / \mathrm{m}^{3}$, while at replacement ratios $(50 \%$ and $100 \%)$ FRCA, there is a reduction in the compressive strength by $(20 \%$ and $34 \%),(23 \%$ and $34 \%)$ and $(23 \%$ and $36 \%)$ at cement contents 300,350 and $400 \mathrm{~kg} / \mathrm{m}^{3}$, respectively, comparing with control concrete. So as the fire duration increase the cohesion between the cement matrix and aggregate is starting to release, leads to the predominance of microcracks where the space between the cement matrix and aggregate increased intermingled with voids due to increase in porosity, the dehydration of calcium hydroxide is take place $\mathrm{Ca}(\mathrm{OH}) 2$, and $\mathrm{C}-\mathrm{S}-\mathrm{H}$ gel. So we can concluded that as the duration of recycled concrete aggregate exposed to fire increased the loss in compressive strength increased at different cement contents and different percentage of replacements.

Table (7) Compressive Strength of Concrete Mixtures at Fire Temperature $600{ }^{\circ} \mathrm{C}$ for Fire Durations $(1,2$, and 3 Hours) at 7 and 28 days

\begin{tabular}{|c|c|c|c|c|c|c|c|}
\hline \multirow{2}{*}{ Group } & \multirow{2}{*}{ Designation } & \multicolumn{3}{|c|}{$\begin{array}{c}\text { Compressive strength at } 7 \\
\text { days }\left(\mathrm{N} / \mathrm{mm}^{2}\right)\end{array}$} & \multicolumn{3}{|c|}{$\begin{array}{c}\text { Compressive strength at } \\
28 \text { days }\left(\mathrm{N} / \mathrm{mm}^{2}\right)\end{array}$} \\
\hline & & 1-hr & 2-hrs & 3-hrs & 1-hr & 2-hrs & 3-hrs \\
\hline \multirow{4}{*}{ G1 } & M1(M-0\%-300) & 22.9 & 22.9 & 22.9 & 28.95 & 28.95 & 28.95 \\
\hline & M2(M-25\%-300) & 21.8 & 20.05 & 19.5 & 29.45 & 28 & 27 \\
\hline & M3(M-50\%-300) & 20.90 & 19.05 & 17.15 & 26.15 & 23.95 & 23 \\
\hline & M4(M-100\%-300) & 18.4 & 16.5 & 14.65 & 24 & 22.05 & 19.5 \\
\hline \multirow{4}{*}{ G2 } & M5(M-0\%-350) & 25.55 & 25.55 & 25.55 & 32.8 & 32.8 & 32.8 \\
\hline & M6(M-25\%-350) & 24.5 & 22.05 & 22 & 32.15 & 31.7 & 30.6 \\
\hline & M7(M-50\%-350) & 23.3 & 20.90 & 19.2 & 28.5 & 26.5 & 25.5 \\
\hline & M8(M-100\%-350) & 21.6 & 19.15 & 17.45 & 26 & 23 & 21.5 \\
\hline \multirow{4}{*}{ G3 } & M9(M-0\%-400) & 28 & 28 & 28 & 37.75 & 37.75 & 37.75 \\
\hline & M10(M-25\%-400) & 27.7 & 23.1 & 23.5 & 37.9 & 36.4 & 33.9 \\
\hline & M11(M-50\%-400) & 25.4 & 22.65 & 20.45 & 33 & 31 & 29 \\
\hline & M12(M-100\%-400) & 24.1 & 21.35 & 19.2 & 30.2 & 27.2 & 24.1 \\
\hline
\end{tabular}


$(\mathrm{M}-\%-\mathrm{C}-\mathrm{G})$

Where

M, refers to mix

$\%$ refers to fire recycled coarse aggregates

$\mathrm{C}$, refers to cement content $\left(\mathrm{kg} / \mathrm{m}^{3}\right)$

$\mathrm{G}$, refers to group number

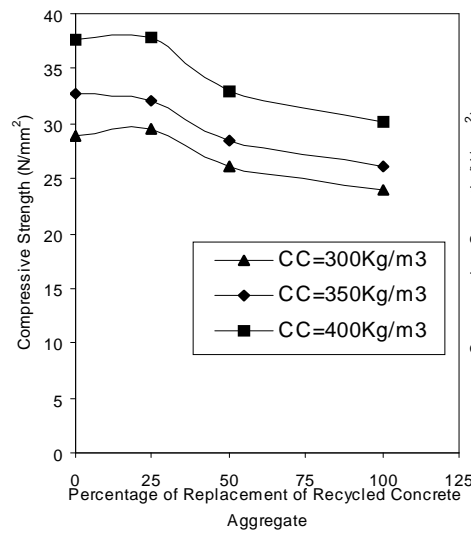

a- Duration - $1 \mathrm{hr}$

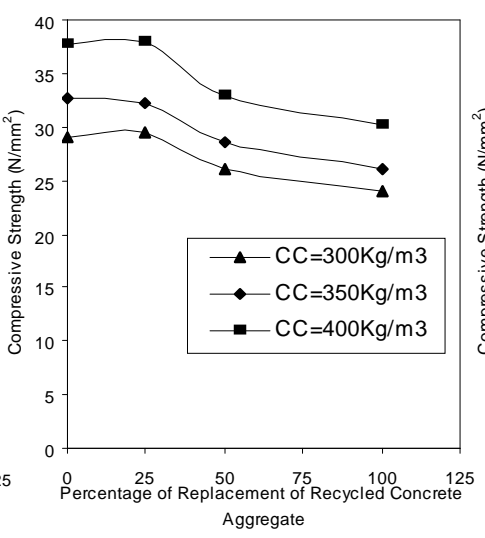

b- Duration $-2 \mathrm{hrs}$

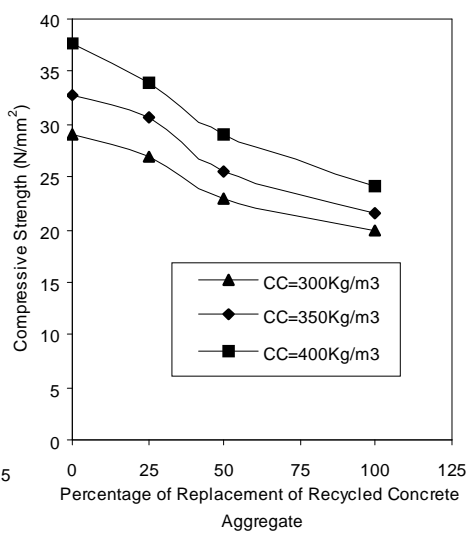

c- Duration - 3 hrs

Fig. (4) Relationship between Compressive Strength and Percentage of Replacement of (RCA) for Different Cement Contents at Fire Temperature $600^{\circ} \mathrm{C}$ at 28 Days

\section{Tensile Strength}

It can be noticed from Fig (5-a) that at replacement ratio 25\%FRCA, there is decrease in the tensile strength by $(5 \%, 4 \%$ and $2 \%)$ at cement contents $\left(300,350\right.$ and $\left.400 \mathrm{~kg} / \mathrm{m}^{3}\right)$ when subjecting to fire temperature $600^{\circ} \mathrm{C}$ for fire duration 1 hour respectively, comparing to control mixtures. While at replacement ratios (50\% and $100 \%)$ FRCA, there is a reduction in the tensile strength by (14\% and 22\%), (12\% and 23\%) and $(12 \%$ and $21 \%)$ at cement contents 300,350 and $400 \mathrm{~kg} / \mathrm{m}^{3}$ respectively, comparing to control mixtures.

It can be noticed from Fig (5-b) that at replacement ratio 25\% FRCA, there is decrease in the tensile strength by $(7 \%, 5 \%$ and $5 \%)$ at cement contents $(300,350$ and $400 \mathrm{~kg} / \mathrm{m}^{3}$ ) when subjecting to fire temperature $600^{\circ} \mathrm{C}$ for 2 hours respectively, comparing to control mixtures. While at replacement ratios (50\% and $100 \%)$ FRCA, there is a reduction in the tensile strength by (17\% and 27\%), (15\% and $25 \%)$ and $(15 \%$ and $26 \%)$ at cement contents 300,350 and $400 \mathrm{~kg} / \mathrm{m}^{3}$ respectively, comparing to control mixtures.

Also, it can be noticed from Fig (5-c) that at replacement ratio 25\% FRCA, there is high decrease in the tensile strength by $(10 \%, 10 \%$ and $7 \%)$ at cement contents $\left(300,350\right.$ and $\left.400 \mathrm{~kg} / \mathrm{m}^{3}\right)$ when subjecting to fire temperature $600^{\circ} \mathrm{C}$ for 3 hours respectively, comparing to control mixtures. While at replacement ratios $(50 \%$ and $100 \%)$ FRCA, there is a reduction in the tensile strength by (19\% and $30 \%),(17 \%$ and $29 \%)$ and (19\% and $31 \%)$ at cement contents 300,350 and $400 \mathrm{~kg} / \mathrm{m}^{3}$ respectively, 
comparing to control mixtures. This agree with Hansen [13] Who stated that the full replacement of RCA, the tensile strength of recycled aggregate concretes produced with both fine and coarse aggregate to be reduced by 35\%. (Notice that that the RCA used in the previous studies was not exposed to fire).

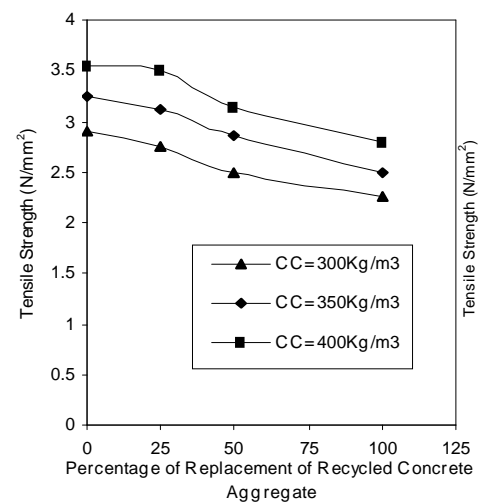

a- Duration - $1 \mathrm{hr}$

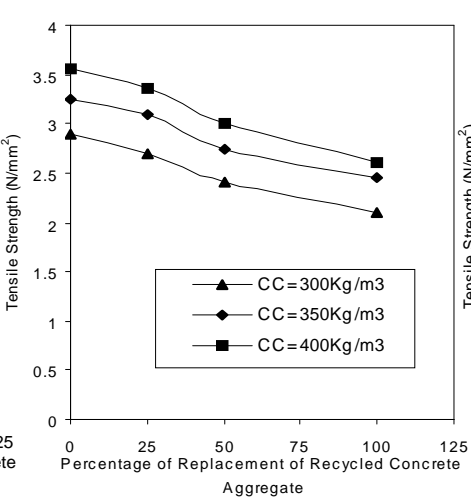

b- Duration - 2hrs

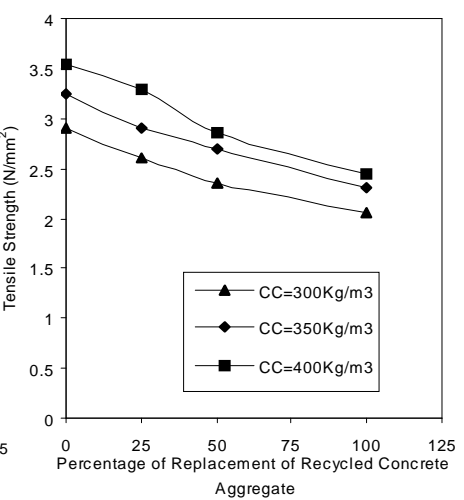

c- Duration - 3 hrs

Fig. (5) Relationship between Tensile Strength and Percentage of Replacement of (RCA) for Different Cement Contents at Fire Temperature $600^{\circ} \mathrm{C}$ at 28 Days

\section{Flexural strength}

Figure (6-a) shows the concrete mixtures subjected to fire temperature $600^{\circ} \mathrm{C}$ for 1hour, it can be noticed that at replacement ratio $25 \%$ FRCA, there is a slight increase in the flexural strength by $1 \%$ at cement content $300 \mathrm{~kg} / \mathrm{m}^{3}$ and decreased by $(1 \%$ and $6 \%$ ) at cement contents $\left(350\right.$ and $\left.400 \mathrm{~kg} / \mathrm{m}^{3}\right)$ respectively, comparing to control mixtures, while at replacement ratios $(50 \%$ and $100 \%)$ FRCA, there is a reduction in the flexural strength by (13\% and 27\%), (18\% and 27\%) and (14\% and 25\%) at cement contents 300,350 and $400 \mathrm{~kg} / \mathrm{m}^{3}$ respectively, comparing with control concrete. This agree with A. Rao et al, [14] Who stated in his literature that the full replacement of RCA, the flexural strength produced with both fine and coarse aggregate reduced by 26 $\%$. ( Notice that the RCA used in the previous studies was not exposed to fire).

Figure (6-b) shows the concrete mixtures subjected to fire temperature $600^{\circ} \mathrm{C}$ for 2 hours, It can be noticed that at replacement ratio 25\%FRCA, there is a decrease in the flexural strength by $(5 \%, 4 \%$ and $9 \%)$ at cement contents $\left(300,350\right.$ and $\left.400 \mathrm{~kg} / \mathrm{m}^{3}\right)$ respectively, comparing to control mixtures, while at replacement ratios $(50 \%$ and $100 \%)$ FRCA, there is a reduction in the flexural strength by $(18 \%$ and $30 \%),(20 \%$ and $31 \%)$ and $(18 \%$ and $30 \%)$ at cement contents 300,350 and $400 \mathrm{~kg} / \mathrm{m}^{3}$ respectively, comparing with control concrete.

Also, figure (6-c) shows the concrete mixtures subjected to fire temperature $600^{\circ} \mathrm{C}$ for 3 hours, It can be noticed that replacement ratio $25 \% \mathrm{FRCA}$, there is decrease in the flexural strength by $(6 \%, 8 \%$ and $5 \%)$ at cement contents $(300,350$ and $400 \mathrm{~kg} / \mathrm{m}^{3}$ ) respectively, comparing to control mixtures, while at replacement ratios $(50 \%$ and $100 \%)$ FRCA there is a reduction in the flexural strength by (24\% and $36 \%)$, $(22 \%$ and $34 \%)$ and $(24 \%$ and $37 \%)$ at cement contents 300,350 and $400 \mathrm{~kg} / \mathrm{m}^{3}$ respectively, comparing with control concrete. 


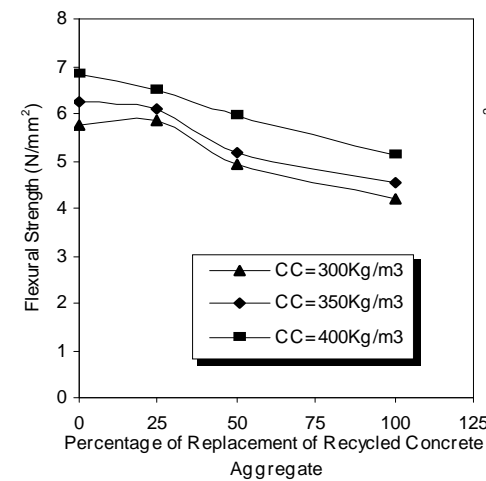

a- Duration - $1 \mathrm{hr}$

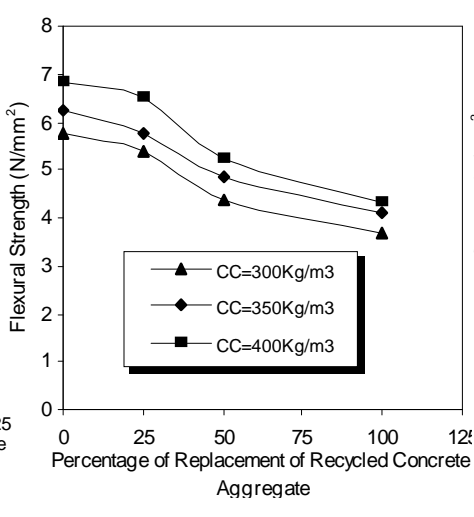

b- Duration - 2hrs

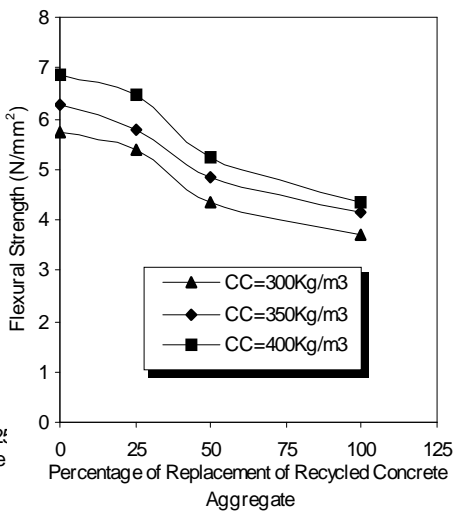

c- Duration - 3 hrs

Fig. (6) Relationship between Flexural Strength and Percentage of Replacement of (RCA) for Different Cement Contents at Fire Temperature $600^{\circ} \mathrm{C}$ at 28 Days

\section{Modulus of Elasticity}

Figure (7-a) shows the concrete mixtures subjected to fire temperature $600^{\circ} \mathrm{C}$ for 1hour, It can be noticed that at replacement ratio $25 \% \mathrm{FRCA}$, there is a reduction in the modulus of elasticity by $(14 \%, 12 \%$ and $14 \%)$ at cement contents $(300,350$ and $400 \mathrm{~kg} / \mathrm{m}^{3}$ ) respectively, comparing to control mixtures, while at replacement ratios $(50 \%$ and $100 \%)$ FRCA, there is a reduction in modulus of elasticity by $(21 \%$ and $39 \%),(22 \%$ and $41 \%)$ and $(20 \%$ and $40 \%)$ at cement contents 300,350 and $400 \mathrm{~kg} / \mathrm{m}^{3}$ respectively, comparing to control mixtures. This may be attributed the presence of more micro cracks and weaker interfaces in recycled aggregate concretes. In addition to large amount of old mortar which is attached to original aggregate particles in recycled aggregates. This agree with Juan and Gutiérrez, [15] Who found out that the elasticity modulus is one of the most affected properties of recycled concretes, for percentages of RCA $20 \%, 50 \%$ and $100 \%$ the values of modulus of elasticity were $10 \%, 20 \%$ and $40 \%$ lower than the corresponding natural aggregate concretes. (Notice that RCA used in the previous studies was not exposed to fire).

Figure (7-b) shows the concrete mixtures subjected to fire temperature $600^{\circ} \mathrm{C}$ for 2 hours, It can be noticed that at replacement ratio $25 \% \mathrm{FRCA}$, there is a reduction in the modulus of elasticity by $(16 \%, 15 \%$ and $17 \%)$ at cement contents $(300,350$ and $400 \mathrm{~kg} / \mathrm{m}^{3}$ ) respectively comparing to control mixtures, while at replacement ratios $(50 \%$ and $100 \%)$ FRCA, there is a reduction in modulus of elasticity by $(24 \%$ and $45 \%),(25 \%$ and $46 \%)$ and $(22 \%$ and $46 \%)$ at cement contents 300,350 and $400 \mathrm{~kg} / \mathrm{m}^{3}$ respectively, comparing with control concrete .

Also, figure (7-c) shows the concrete mixtures subjected to fire temperature $600^{\circ} \mathrm{C}$ for 3 hours, It can be noticed that replacement ratio $25 \% \mathrm{FRCA}$, there is a reduction in the modulus of elasticity by $(18 \%, 19 \%$ and $20 \%)$ at cement contents $(300,350$ and $400 \mathrm{~kg} / \mathrm{m}^{3}$ ) respectively, comparing to control mixtures, while at replacement ratios $(50 \%$ and $100 \%)$ FRCA, there is a reduction in modulus of elasticity by $(25 \%$ and $51 \%),(27 \%$ and $52 \%)$ and $(24 \%$ and $51 \%)$ at cement contents 300,350 and $400 \mathrm{~kg} / \mathrm{m}^{3}$ respectively, for different cement content when compared with the control concrete. 


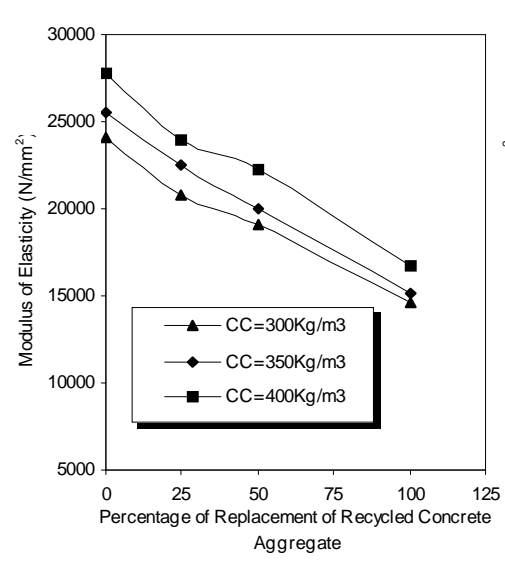

a- Duration - $1 \mathrm{hr}$

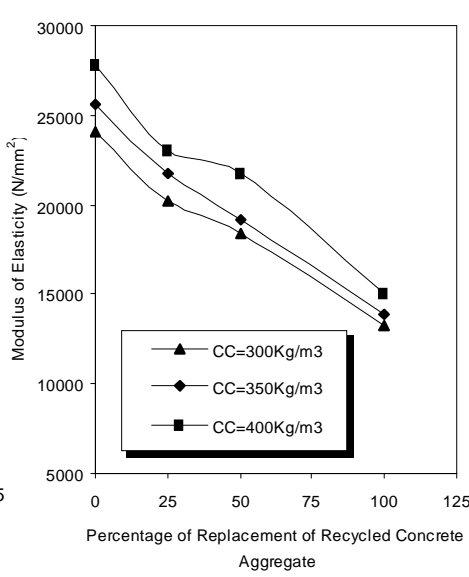

b- Duration - 2hrs

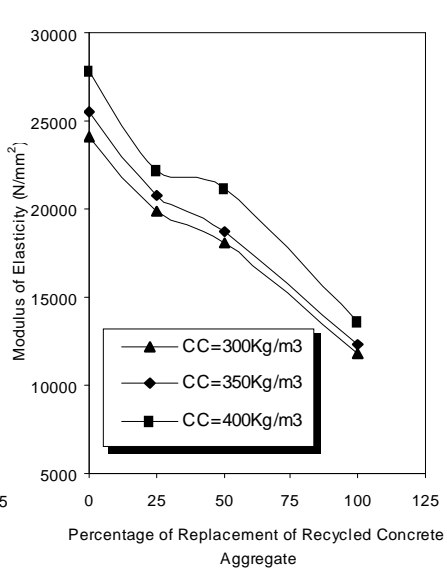

c- Duration - 3 hrs

Fig. (7) Relationship between Modulus of Elasticity and Percentage of Replacement of (RCA) for Different Cement Contents at Fire Temperature $600^{\circ} \mathrm{C}$ at 28 Days

\section{CONCLUSIONS}

1- The variation in density and water absorption ratio of fired recycled concrete aggregates are much higher than those of natural aggregates. The variations are mainly due to the adhered mortar as reported by many other researchers. This may cause a quality control problem.

2- The dosage of superplasticizer was increased significantly by increasing percentage of replacement ratio of recycled concrete aggregates in the concrete mixtures to achieve acceptable workability of concrete.

3- The high strength relative observed in mixtures with $300 \mathrm{~kg} / \mathrm{m}^{3}$ cement content, so it can be concluded that it could be more useful to use recycled concrete aggregates in lower strength concrete.

4- Replacement of natural aggregate by $25 \%$ recycled concrete aggregates subjected to fire temperature $600^{\circ} \mathrm{C}$ for fire durations $(1,2$ and 3hours) has a very minor effect on both of compressive, tensile strength and flexural strength.

5- The compressive strength of concretes containing full replacement of natural aggregate by recycled aggregates subjected to fire temperature $600^{\circ} \mathrm{C}$ for fire durations (1,2 and 3hours) decreased with range (18\% to $36 \%$ ), comparing to control mixtures.

6- The tensile strength of concretes made with $100 \%$ recycled concrete aggregate subjected to fire temperature $600^{\circ} \mathrm{C}$ for fire durations (1,2 and 3hours) decreased with range ( $23 \%$ to $30 \%$ ), comparing to control mixtures.

7- The modulus of elasticity of concretes made with $100 \%$ recycled concrete aggregate subjected to fire temperature $600^{\circ} \mathrm{C}$ for fire durations $(1,2$ and 3hours) decreased with range ( $40 \%$ to $50 \%$ ), comparing to control mixtures. 


\section{REFERENCES}

[1] C.Poon, S .Kon, L .Lemi. (2007) "Influence of Recycled Aggregate on Slump and Bleeding of Fresh Concrete" Material Structural, Vol. 40, pp 981-988.

[2] S .Tabsh, A .Abdelfalah. (2009)"Influence of Recycled Concrete Aggregate on Strength Properties", Construction Building Materials, Vol. 23, pp 1163-1170.

[3] Esraa Emam Ali, Sherif H. Al-Tersawy, "Self Compacting Concrete Using Recycled Concrete Aggregates", (2010), HBRC Journal, Egypt.

[4] J.A .Purkiss. " An Engineering Model for Coupled Heat and Heat and Mass Transfer Analsyis in Heated Concrete" School of Scinece and Applied Science, Aston University, Birmingham,UK,july (2001).

[5] Esraa Emam Ali, (2008), "The Behaviour of Rienforced Concerto Frames Subjected to Fire“ Phd. Thesis, Faculty of Engineering, Helwan University, Egypt.

[6] Vieira, J.P.B., Correia, J.R., Brito, J. de .(2011)" Post-fire residual mechanical properties of concrete made with recycled concrete coarse aggregates coarse aggregates" Journal of Cement and Concrete Research, Vol. 41 ,pp 533-541.

[7] ESS 2421/2005, Egyptian Standard Specification "Cement-Physical and Mechanical Tests".

[8] ESS 1109/2002, Egyptian Standard Specification, "Aggregate for Concrete".

[9] Egyptian Code of Practice for Design and Construction of Concrete Structures ECCS (203-2007).

[10] Dina Mahmoud Sadek. (2008) "Durability of Concrete Containing Some Local Industrial Wastes" Phd. Thesis, Faculty of Engineering, Cairo University, Egypt.

[11] M. Etxeberria, E. Vázquez, A. Marí, M. Barra.(2007) "Influence of amount of recycled coarse aggregates and production process on properties of recycled aggregate concrete "Journal of cement and concrete research, Vol. 37, pp 753742.

[12] Fatma Al Zahraa Ibrahim Abd El-Latif. (2009) "Structural Behavior of Reinforced Concrete Beams With Recycled Concrete Aggregates". Msc. Thesis, Faculty of Engineering, Cairo University, Egypt.

[13] T. C. Hansen "Concretes of Demolished Concrete and Masonry" Report of Technical Committee 37 -DRC -Demolition and Reuse of Concrete , Hartnolls Ltd ,Bodmin, Great Britain, 1992.

[14] A .Rao, K. Jha, S.Misra. (2007) "Use of aggregates from recycled construction and demolition waste in concrete" Journal of Resources Conservation and Recycling, Vol. 50, pp 71-81.

[15] M.S. Juan , P.A. Gutiérrez "Influence of Attached Mortar Content on the Properties of Recycled Concrete Aggregate", International RILEM Conferences on the Use of Recycled Materials in Building and Structures , Barcelona, Spain,9-11 November 2004. 


\section{الخواص الميكانيكية للخرسانة التي تحتوي على ركام الخرسانة المعاد تدويره والمعرض \\ للحريق لفترات زمنية مختلفة}

تلاحظ في الآونة الأخيرة الزيادة المطردة في المخلفات الناتجة عن هدم الخرسانة حيث يتم التخلص منها عن

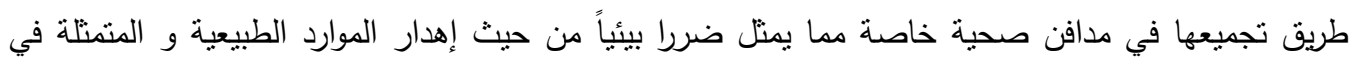
الركام الطبيعي ومن ثم بدأ التفكير في أنحاء متفرقة من العالم في استغلال هذه المخلفات عن طريق إعادة استخدامها في إنتاج الخرسانة بحيث تحل محل الركام بنسب مختلفة و ذلك بعد تكسير مخلفات الخرسانة باستخدام الكسارات للوصول الى المقاسات المطلوبة. و رغم وجود العديد من الأبحاث التي تم من خلالها دراسة

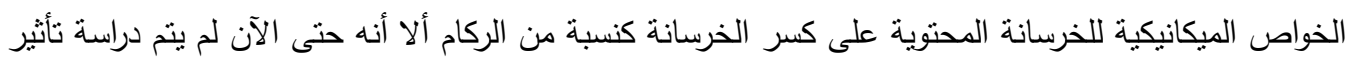

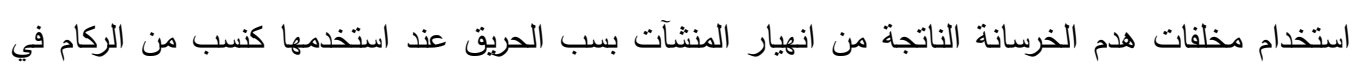
الخرسانة .

ولذلك فان هذه الدراسة تعنتي بدراسة تأثير زمن تعرض ركام الخرسانة المعاد تدويره والمعرض للحريق علي

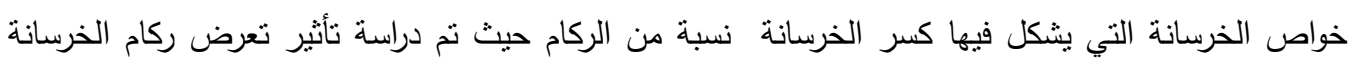
المعاد تدويره والمعرض للحريق عند درجة حرارة 600 درجة مئوية لفترات زمنية متغيرة لمدة ساعة و ساعتين وثلاث ساعات و ذلك لعدد من الخلطات الخرسانية المختلفة (30 خلطة خراسانية) من حيث محتوي الأسمنت (300 و 350 و 400 كجم/23) وكذلك نم الأخذ في الاعتبار نسبة استبدال الركام الطبيعي الكبير بناتج كسر الخرسانة (0\% و 25\% و 50\% و 100\%) وتنتعرض نتائج الدراسة الخواص المختلفة للخرسانة مثل الخواص الطازجة (اختبار الهبوط) والخواص المنصلده مثل (مقاومة الضغط - مقاومة الثد - مقاومة الانحناء- معامل 